\title{
Normalizing Heat Treatment Effect on Low Alloy Steel Weld Metals
}

V. B. da Trindade Filho

A. S. Guimarães and

J. da C. Payão Filho

Universidade Federal do Rio de Janeiro $\mathrm{CT}$, Enga Metalúrgica e de Materiais P.O. Box 68.505

Cidade Universitária, Ilha do Fundão

21941-972 Rio de Janeiro, RJ. Brazil vicente@ifwt.mb.uni-siegen.de asauer@ufrj.br and jpayao@metalmat.ufrj.edu.br

\section{R. P. da R. Paranhos \\ Universidade Estadual do Norte Fluminense Centro de Ciência e Tecnologia \\ Laboratório de Materiais Avançados \\ Av. Alberto Lamego 2000, Parque Califórnia 28015-620 Campos dos Goytacases, RJ \\ Brazil \\ paranhos@uenf.br}

In equipment manufacturing, there are occasions that the base metal (BM) need to be hot or cold worked prior to welding. After welding, the components have to be submitted to a normalizing heat treatment in order to recover its original mechanical properties. In this work four different low alloy steel weld metals (WM) both in the as welded condition and after normalizing heat treatment have been studied. Optical and scanning electron microscopy were used to observe the WM microstructure. Tensile and Charpy V toughness testing and microhardness measurements were used to evaluate the WM mechanical properties. Results show that normalizing breaks the original columnar structure in the as welded condition to an equiaxial structure similar to the one of the BM. Due to low carbon content of the WM it was observed a high decrease on the tensile properties specially the yield strength after normalizing. In respect of toughness, the normalizing heat treatment was observed to increase the Charpy $V$ energy, except for one WM where a great content of martensite-austenite-bainite constituent was formed. Opposite to others post weld heat treatments, normalizing modifies significantly the microstructure and the resulting mechanical properties of the WM. Although normalizing is always beneficial to the BM, care must be taken in order to select welding consumables.

Keywords: Welding, low alloy steel weld metal, normalizing heat treatment

\section{Introduction}

The weld metal metallurgy for C-Mn and low alloy steels differs significantly from the base metal metallurgy in several aspects: heating and cooling rates of a weld are much more faster than those of a steel base metal during its manufacturing process; the microstructure of the weld metal is columnar and as melted, and it was not submitted to any subsequent thermo-mechanical treatment; weld metal carbon content is usually kept below $0.10 \%$, while C-Mn and low alloy structural steels have $0.12 \% \mathrm{C}-0.25 \% \mathrm{C}$; it is observed that C-Mn and low alloy steel weld metal microstructure is a complex mixture of two or more constituents, such as proeutectoide ferrite, polygonal ferrite, aligned and non-aligned side plate ferrite, ferrite-carbide aggregate and acicular ferrite (IIW, 1988). When alloying elements are added to the weld metal, upper and lower bainite, martensite and the A-M (austenite with martensite) microconstituent may be formed (Grong, 1992; Evans, 1991); tensile properties of the weld metal are relatively high when compared to those of a base metal of similar chemical composition.

The manufacturing of equipments by welding usually requires cold forming and for few cases hot forging of steel plates in order that they acquire specific shapes. When working with thick plates, welding generates a high level of residual stresses, and it is usual to perform a stress relieve heat treatment after welding. This is always done at temperatures between $600^{\circ} \mathrm{C}-700^{\circ} \mathrm{C}$, well below $\mathrm{Ac}_{1}$, and therefore it does not change significantly the microstructure and mechanical properties of both base and weld metals. In some few cases, when the steel is hot or cold worked, it is necessary to perform a normalizing heat treatment in order to recover its original mechanical properties. As normalizing involves heating above $\mathrm{Ac}_{3}$ in order to promote the base metal grain refinement, this will change the original characteristics of an as welded structure. The effect of

Presented at COBEF 2003 - II Brazilian Manufacturing Congress, 18-21 May 2003, Uberlândia, MG. Brazil.

Paper accepted October, 2003. Technical Editor: Alisson Rocha Machado the normalizing heat treatment on the weld metal microstructure has not been yet well studied on the literature. The present work has as objective the evaluation of the microstructure and mechanical properties of C-Mn and low alloy steel weld metals after normalizing heat treatment.

\section{Experimental Procedure}

Four "all weld metal" joints were made with submerged-arc welding, and the adopted welding procedure was according to AWS A.5.23-97. As consumables, it was used a neutral flux and four different wires: $\mathrm{CMn}(1.2 \% \mathrm{Mn})$, CMnMo $(1.7 \% \mathrm{Mn}, 0.5 \% \mathrm{Mo})$, $\mathrm{CMnMoCr} \quad(0.5 \% \mathrm{Mn}, \quad 0.5 \% \mathrm{Mo}, \quad 1.3 \% \mathrm{Cr})$ and $\mathrm{CMnMoTiB}$ (1.2\%Mn, $0.5 \% \mathrm{Mo}, 0.16 \% \mathrm{Ti}, \quad 0.010 \% \mathrm{~B})$. Table 1 shows the welding parameters used.

Table 1. Welding parameters and data.

\begin{tabular}{ll}
\hline \multicolumn{1}{c}{ Parameter } & \multicolumn{1}{c}{ Data } \\
\hline Welding current & $550 \mathrm{~A}$ \\
Type of current & $\mathrm{CC}^{+}$ \\
Voltage & $28 \mathrm{~V}$ \\
Welding speed & $40 \mathrm{~cm} / \mathrm{min}$ \\
Number of beads & 17 \\
Interpass temperature & $163^{\circ} \mathrm{C}$ \\
Welding time & $80 \mathrm{~s}$ \\
Wire diameter & $3.97 \mathrm{~mm}$ \\
Groove opening & $16 \mathrm{~mm}$ \\
Heat input & $2.31 \mathrm{~kJ} / \mathrm{mm}$ \\
Backing & Steel \\
\hline
\end{tabular}

The normalizing heat treatment was made heating the welding joints at a rate of $200^{\circ} \mathrm{C} / \mathrm{h}$ from ambient temperature up to $920^{\circ} \mathrm{C}$ and remained at this temperature for $2 \mathrm{~h}$. Afterwards, they were removed from the oven and air cooled up to the ambient temperature.

Quantitative metallography was carried out only on the weld metals in the as welded condition. Samples were etched with 
nital 2\%, and image acquisition was performed with 500x magnification at 30 different fields in the columnar zone (last weld bead). It was used a grid of 42 points for each sample (Voort and George, 1984). IIW DOC IX-1533-88 (IIW, 1988) was used to identify and classify the weld metal microstructure. For the normalized condition the average ferrite grain size was measured by the intercept method. The ASTM number was calculated according to the Voort equation (Voort and George, 1984). Scanning electron microscopy (SEM) was used in order to analyze microphase in weld metals in both conditions, as welded (AW) and after normalizing heat treatment $(\mathrm{N})$. For SEM analysis, weld metals were etched with a solution of $50 \%$ in volume of nital $2 \%$ plus $50 \%$ in volume picral $2 \%$.

Mechanical testing were performed for both as welded and normalized condition: all weld metal tension test, Charpy V impact testing at three different temperatures $\left(-20^{\circ} \mathrm{C}, 0^{\circ} \mathrm{C}\right.$ and $\left.+30^{\circ} \mathrm{C}\right)$, and Vickers microhardness with $100 \mathrm{~g}$ (HV 0.1) at $2 \mathrm{~mm}$ below the weld joint surface.

\section{Results and Discussion}

\section{Weld Metal Chemical Composition}

Table 2 shows the chemical composition (weight percent) and the carbon equivalent of the four all weld metal joints. Carbon, manganese, silicon, phosphor and sulphur contents are considered to be relatively constant for the range studied.

Table 2. Chemical composition (\% weight) and carbon equivalent (CE) of the weld metals.

\begin{tabular}{|c|c|c|c|c|c|c|c|c|c|c|}
\hline \multirow[t]{2}{*}{ Weld metal } & \multicolumn{9}{|c|}{ Chemical composition (\% weight) } & \multirow{2}{*}{$\begin{array}{l}\text { Carbon } \\
\text { equivalent }\end{array}$} \\
\hline & C & Mn & Si & $\mathbf{P}$ & $\mathrm{S}$ & Mo & $\mathrm{Cr}$ & $\mathbf{T i}$ & B & \\
\hline CMn & 0.08 & 1.63 & $\overline{0.40}$ & 0.022 & 0.015 & - & - & - & - & 0.29 \\
\hline CMnMo & 0.05 & 1.70 & 0.23 & 0.024 & 0.021 & 0.50 & - & - & - & 0.42 \\
\hline CMnMoTiB & 0.08 & 1.58 & 0.31 & 0.021 & 0.016 & 0.48 & - & 0.012 & 0.0018 & 0.44 \\
\hline CMnMoCr & 0.05 & 1.25 & 0.32 & 0.024 & 0.015 & 0.52 & 1.06 & - & - & 0.52 \\
\hline
\end{tabular}

\section{As Welded Microstructure}

Table 3 shows the results of the performed quantitative metallography and grain size measurement on weld metals in the as welded condition.

Table 3. Results of the quantitative metallography performed on weld metals in the as welded condition, where $A F=$ acicular ferrite, $P F(G)=$ proeutectoide ferrite, $\operatorname{PF}(I)=$ polygonal ferrite, $F S(A)=$ aligned side plate ferrite, FC = ferrite-carbide aggregate; and weld metal ferrite grain size after the normalizing heat treatment.

\begin{tabular}{lccccccc}
\hline Weld metal & \multicolumn{4}{c}{ Constituent content [\%] } & \multicolumn{3}{c}{$\begin{array}{c}\text { Grain size } \\
\text { (normalized) }\end{array}$} \\
\hline & AF & PF & PF & FS & FC & $\mu \mathbf{m}$ & ASTM \\
& & (G) & (I) & (A) & & & \\
\hline CMn & 25 & 32 & 14 & 27 & 2 & 20 & 8 \\
CMnMo & 42 & 17 & 19 & 21 & 2 & 23 & 8 \\
CMnMoTiB & 76 & 12 & 5 & 5 & 2 & 25 & 7 \\
CMnMoCr & 44 & 9 & 8 & 36 & 3 & 23 & 8 \\
\hline
\end{tabular}

The CMn weld metal showed a great content of proeutectoid boundary ferrite (32\%), 14\% polygonal ferrite, $27 \%$ aligned side plate ferrite and only $25 \%$ of acicular ferrite. A typical photomicrograph of these weld metal constituents is shown in Fig. 1 . The addition of $0.50 \% \mathrm{Mo}$ (CMnMo weld metal) promoted the increase of acicular ferrite to $42 \%$ and polygonal ferrite to $19 \%$, while the others ferrite morphology types were significantly reduced (except for FC), showing the effect of Mo on promoting a microstructure refinement. The addition of Ti-B (CMnMoTiB weld metal) promoted an additional increase of acicular ferrite content to $76 \%$, showing the strong effect of $\mathrm{Ti}$ and $\mathrm{B}$ addition on microstructure refinement. The ability of B to promote acicular ferrite is said (Ortega, 1999) to be dependent of Ti presence, which combines with both $\mathrm{C}$ and $\mathrm{N}$ of the weld metal, allowing $\mathrm{B}$ to segregate at austenite grain boundary, and than reducing the austenite-ferrite transformation temperature.

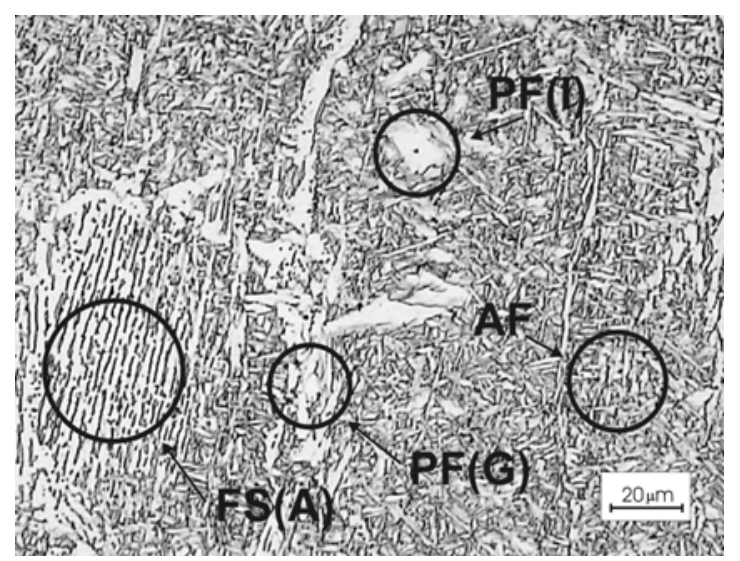

Figure 1. Optical microscopy of the CMn weld metal in the as welded condition showing acicular ferrite (AF), proeutectoide ferrite (PF(G)), polygonal ferrite (PF(I)) and aligned side plate ferrite (FS(A)).

The effect of $1.06 \% \mathrm{Cr}$ addition can be observed comparing CMnMoCr with CMnMo weld metal. Although acicular ferrite contents of these weld metals are almost the same (44\% and $42 \%$, respectively, see Tab.3), it can be observed the effect of $\mathrm{Cr}$ increasing the aligned side plate ferrite content and reducing the polygonal and proeutectoid ferrite contents. This is also attributed to the higher Mn content of CMnMo weld metal (see Tab. 2), because $\mathrm{Mn}$ is considered to be more effective than $\mathrm{Cr}$ to reduce the austenite-ferrite temperature transformation.

The amount of ferrite-carbide aggregate in all weld metals remained in the range of $2 \%-3 \%$. In fact, optical metallography does not have enough resolution to correctly identify microconstituents on the weld metal, witch become clear only with the aid of SEM analysis.

SEM analysis of the weld metals showed that CMn weld metal has only ferrite-carbide as microconstituent (Fig. 2a). In the others three weld metals the A-M microconstituent was identified, as shown in Fig. 2b. A qualitative analysis showed a higher content of A-M microconstituent in the $\mathrm{CMnMoCr}$ weld metal, followed by CMnMoTiB and CMnMo weld metals. It is known (Ortega, Payão 
Filho and Paranhos, 1999) the harmful effect of the A-M microconstituent on the weld metal toughness.

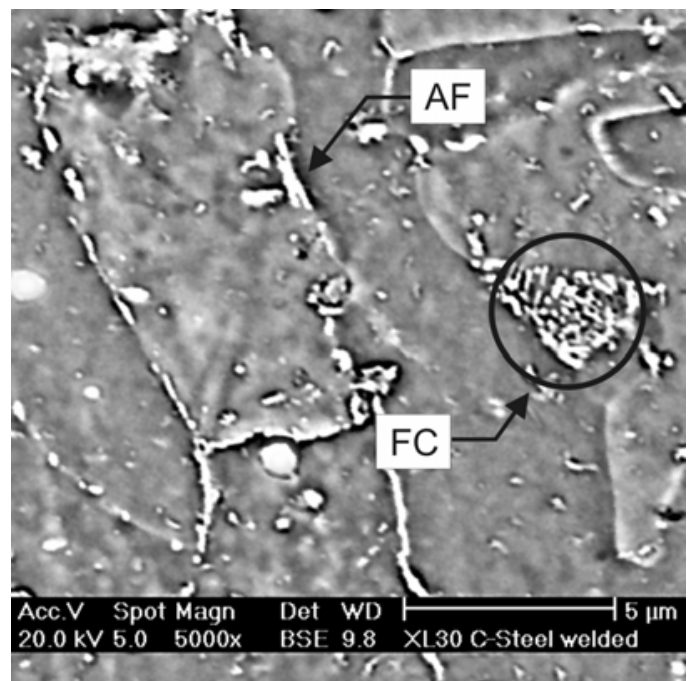

(a)

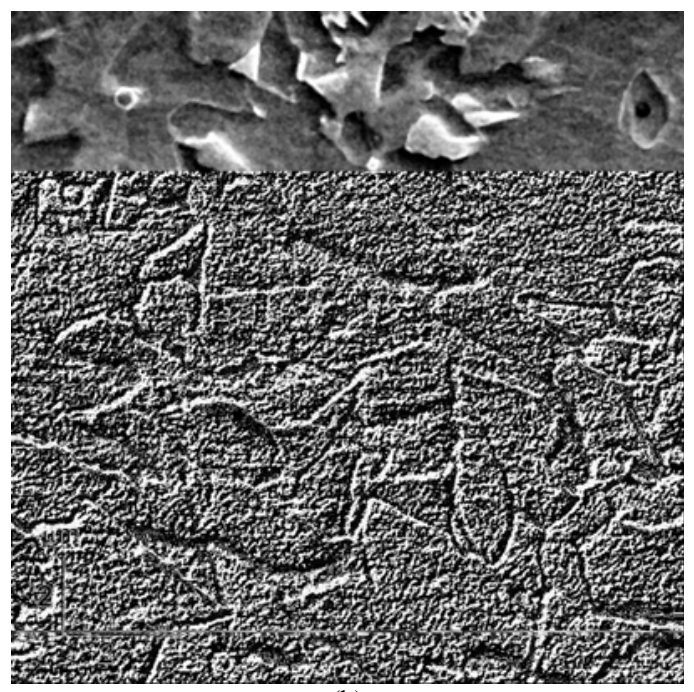

(b)

Figure 2. Scanning electron microscopy of weld metals in the as welded condition showing (a) ferrite-carbide aggregate (CMn weld metal), and (b) the A-M (austenite-martensite) microconstituent (CmnMoTiB weld metal).

\section{Normalized Microstructure}

For the weld metals studied, the normalizing heat treatment changed the original as welded microstructures (Fig. 1) to an equiaxed ferrite microstructure with ferrite-carbide aggregates. Figure 3 shows a typical optical microstructure of the CMnMo weld metal after the normalizing heat treatment. The complete austenitization of the weld metal imposed by the normalizing heat treatment, associated with its significantly lower thermal cycles when compared with the welding thermal cycles, generates a coarser equiaxed ferrite when compared to the as welded microstructure rich in acicular ferrite (Fig. 1). The grain size (measured in $\mu \mathrm{m}$ ) and the corresponding ASTM number of the normalized equiaxed ferrite are shown in Tab. 3. It can be observed that the grain size of equiaxed ferrite is kept relatively constant for all weld metals, with $20 \mu \mathrm{m}$ for the CMn weld metal and $23 \mu \mathrm{m}-25 \mu \mathrm{m}$ for the three low alloyed weld metals.

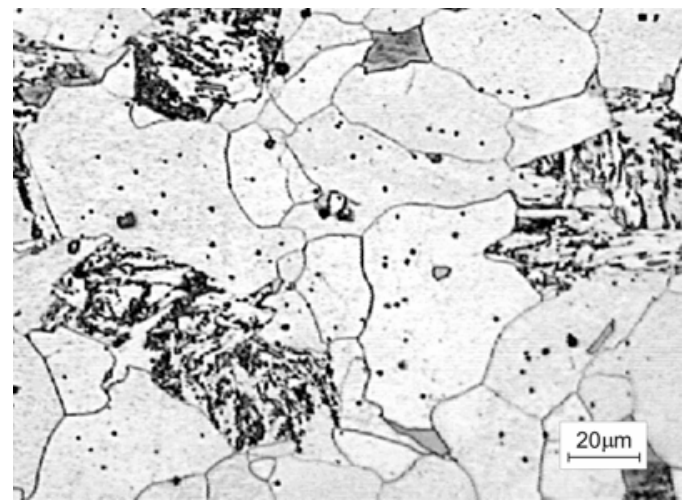

Figure 3. Optical microscopy of the CMnMo weld metal after the normalizing heat treatment showing equiaxial ferrite grains and ferritecarbide aggregate.

SEM was used to identify ferrite-carbide aggregates observed by optical microscopy after weld metal normalization. For the CMn weld metal, perlite and cementite film at the equiaxed grain boundary ferrite was observed (Fig. 4a). For the low alloy weld metals, Fig. 4b shows an aggregate consisting of three constituents: martensite, retained austenite and bainite. This was also observed by Evans and Bailey (1997) and it was called as M-A-B constituent.

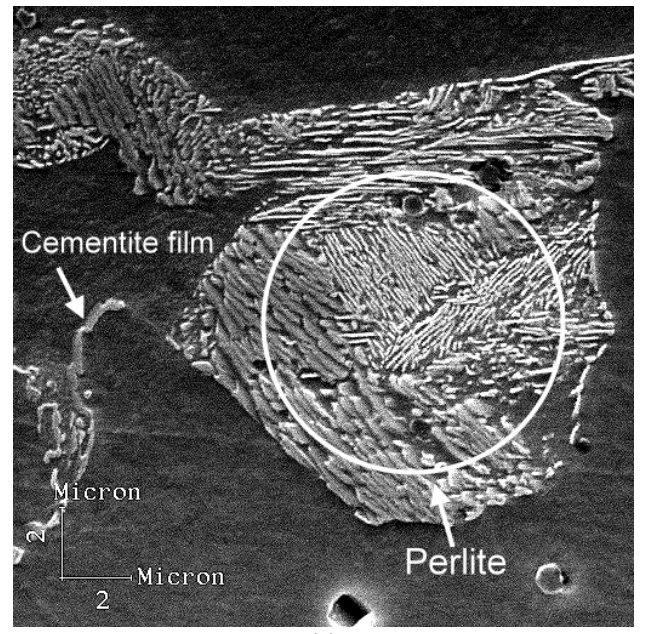

(a)

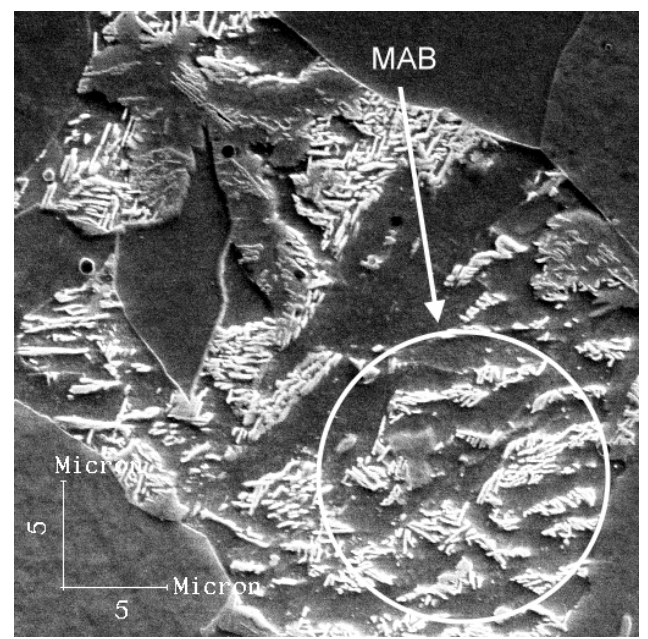

(b)

Figure 4. Scanning electron microscopy of normalized weld metal showing (a) perlite and cementite film at ferrite grain boundary (CMn weld metal), and (b) M-A-B constituent (CMnMoTiB weld metal). 


\section{Mechanical Properties}

\section{Vickers Hardness}

Table 4 shows the weld metals Vickers hardness for the as welded and normalized conditions. For the as welded condition, hardness was $170 \mathrm{HV} 0.1$ for the CMn weld metal and $180 \mathrm{HV} 0.1-$ $198 \mathrm{HV} 0.1$ for the low alloyed weld metals. After normalizing, CMn weld metal was the only weld metal which experienced a significant drop in hardness (51 HV 0.1), while for the low alloyed weld metals hardness remained almost with the same values as the as welded condition. This is attributed to the solid solution strengthening due to the addition of alloying elements (Mo, Cr, Ti and B) and to the formation of M-A-B constituent in the low alloyed weld metals.

Table 4. Mechanical properties of the weld metals in the as welded and normalized conditions, where YS = yield strength, UTS = ultimate tensile strength, $\mathrm{EI}=$ elongation and $\mathrm{RA}=$ reduction of area; and Vickers microhardness with $100 \mathrm{~g}$ (HV 0.1).

\begin{tabular}{|c|c|c|c|c|c|}
\hline \multirow[t]{2}{*}{ Weld metal } & \multicolumn{4}{|c|}{ Mechanical properties } & \multirow{2}{*}{$\begin{array}{c}\text { Vickers } \\
\text { micro- } \\
\text { hardness } \\
\text { (HV 0.1) }\end{array}$} \\
\hline & $\begin{array}{c}\text { YS } \\
\text { [MPa] }\end{array}$ & $\begin{array}{c}\text { UTS } \\
\text { [MPa] }\end{array}$ & $\begin{array}{c}\text { El } \\
{[\%]}\end{array}$ & $\begin{array}{l}\text { RA } \\
{[\%]}\end{array}$ & \\
\hline \multicolumn{6}{|l|}{ As welded } \\
\hline$\overline{\mathrm{CMn}}$ & 434 & 585 & 30 & 72 & 170 \\
\hline CmnMo & 500 & 605 & 25 & 66 & 194 \\
\hline CMnMoTiB & 545 & 620 & 27 & 63 & 180 \\
\hline $\begin{array}{l}\text { CMnMoCr } \\
\text { Normalized }\end{array}$ & 565 & 685 & 24 & 58 & 198 \\
\hline$\overline{\mathrm{CMn}}$ & 305 & 448 & 38 & 74 & 119 \\
\hline CmnMo & 244 & 472 & 36 & 70 & 186 \\
\hline CMnMoTiB & 241 & 454 & 36 & 74 & 179 \\
\hline CMnMoCr & 248 & 510 & 33 & 61 & 205 \\
\hline
\end{tabular}

\section{Tensile Properties}

Table 4 shows the mechanical properties for the four weld metals in the as welded and normalized conditions. For the as welded condition, yield and tensile strength increase in the following order: CMn, CMnMo, CMnMoTiB and CMnMoCr. These results are consistent with the degree of alloying addition in the weld metals (which can be measured by the carbon equivalent values shown in Tab. 2) and the associated solid solution strengthening. In addition, low alloyed weld metals have a higher content of fine acicular ferrite, which has a high dislocation density and high angle grain boundary. Elongation and reduction of area, as expected, showed opposite behavior, i. e., have been reduced while carbon equivalent was increased.

For the normalized condition, Tab. 4 shows a remarkable drop in yield strength when compared to the as welded condition, although the tensile strength also was decreased for all weld metals. This is attributed to the austenitization and low cooling rates characteristic of the normalizing heat treatment, producing a matrix of coarse equiaxial ferrite. It is known that the as welded metal and acicular ferrite have a high dislocation density which combined with the small grain size of the acicular ferrite produces a considerable high yield and tensile strength. Elongation and reduction of area, as expected, showed opposite behavior, i. e., have been increased while yield and tensile strength was reduced.

\section{Charpy V Toughness}

Figure 5 shows Charpy V results for the weld metals in the as welded and normalized conditions. For the as welded condition, Charpy V energy at $-20^{\circ} \mathrm{C}$ is higher for CMn weld metal, followed by $\mathrm{CMnMoTiB}, \mathrm{CMnMo}$ and $\mathrm{CMnMoCr}$. Only this last one presents results near the minimum threshold of $27 \mathrm{~J}$ usually required for pressure vessel manufacturing. It is known in the literature the beneficial effect of acicular ferrite on toughness (Ortega, Payão Filho and Paranhos, 1999), although in the present work CMn weld metal showed the lowest content of acicular ferrite among all weld metals studied (Tab. 3) and the greater values of impact toughness. The lower toughness of the low alloy weld metals is attributed to the presence of A-M microconstituent on the as welded microstructure, as mentioned earlier (section 3.2), and to its harmful effect on the toughness of the weld metal.

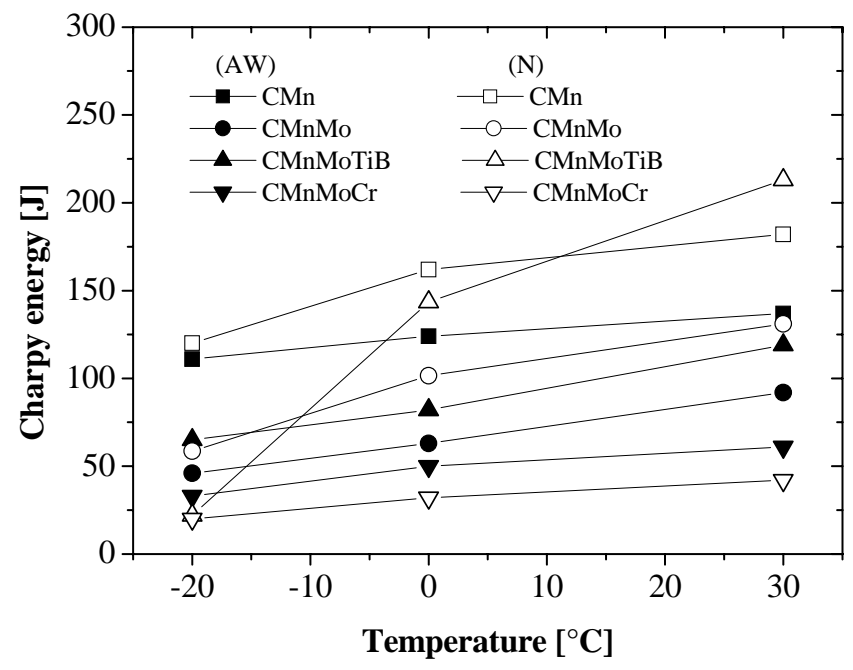

Figure 5. Charpy $V$ energy of the weld metals in the as welded (AW) and normalized $(\mathrm{N})$ conditions for three different temperatures $\left(-20^{\circ} \mathrm{C}, 0^{\circ} \mathrm{C}\right.$ and $\left.+30^{\circ} \mathrm{C}\right)$.

For the weld metals in the normalized condition, Fig. 5 shows that Charpy V energy at $-20^{\circ} \mathrm{C}$ is higher for the CMn weld metal, followed by $\mathrm{CMnMo}$, CMnMoTiB and CMnMoCr. The last two weld metals present results below the threshold of $27 \mathrm{~J}$, limiting its use for the normalized condition. The low toughness values are attributed to the presence of M-A-B constituent observed for the three low alloyed weld metals which, similar to the A-M constituent observed in the as welded condition, is considered to be harmful to toughness.

The results obtained in the present work allow to choose welding consumables for both the as welded and after normalizing condition. It is supposed that steels used for pressure vessel manufacturing usually have 470MPa minimum tensile strength and impact toughness greater than $27 \mathrm{~J}$ at $-20^{\circ} \mathrm{C}$. In this case, for the as welded condition, CMn wire is considered as the better choice. For the normalized condition, CMnMo weld metal is considered to obtain the better compromise between toughness at $-20^{\circ} \mathrm{C}$ and tensile strength. Despite it, attention should be given to the low yield strength obtained for all weld metals, because for many engineering purposes yield strength is the required property used in the design of equipments.

\section{Conclusions}

From this work, it is possible to draw the following conclusions when evaluating the effect of normalizing heat treatment on weld metal properties:

- the original as welded metal fine grained microstructure is changed to a coarse equiaxed ferrite with ferrite-carbide aggregates; 
- yield and tensile strength properties are considerably reduced;

- low alloyed weld metal (CMnMo, CMnMoTiB and CMnMoCr) developed M-A-B constituent, which impaired toughness at low temperatures;

- CMnMo weld metal presented the better compromise between tensile strength and toughness at low temperature.

\section{Acknowledgement:}

FAPERJ, CAPES and CARBOOX are gratefully acknowledged for financial support.

\section{References}

Evans, G.M. and Bailey, N., 1997, "Metallurgy of Basic Weld Metal", Abington Publishing, Cambridge, London, UK.
Evans, G.M., 1991, "The Effect of Nickel n Microstructure and Properties of C-Mn All-Weld Metal Deposits", Welding Research Abroad 37, Vol. 41.

Grong, O., 1992, "Microstructure and Properties of Steel Weld Metals", in: D.L. Olson \& T.H. North (eds.), Ferrous Alloys Weldments, Trans. Tech. Publications, pp. 21-46.

IIW, 1988, "Guidelines for the Classification of Ferritic Steel Weld Metal Microstructure Constituents using the Light Microscopy; International Institute of Welding, IIW DOC. IX-1533-88

Ortega, L.P.C., 1999, "Efeito da Adição de Boro e Titânio na Microestrutura e Tenacidade do Metal de Solda Obtido por Arco submerso em Juntas de Dois Passes”. M.Sc. Thesis, Federal University of Rio de Janeiro, Metalurgical and Materials Department, Rio de Janeiro (RJ), Brazil.

Ortega, L.P.C., Payão Filho, J.C. and Paranhos, R.P.R., 1999, “Emprego de Planejamento de Experimentos na Análise Microestrutural e Tenacidade de Soldas de Arco Submerso" Soldagem \& Inspeção, Ano 5, No. 12, pp. 111.

Voort, V. and George, F., 1984, "Metallography. Principles and Practice", McGraw-Hill Book Company, USA. 